\title{
MANAJEMEN HEAD MASTER DALAM MENINGKATKAN KOMPETENSI PROFESIONALISME GURU DI SMAN II KABUPATEN BANGKALAN
}

\author{
Badrut Tamam \\ STAI Nazhatut Thullab Sampang \\ Email: tamam.badrut43@yahoo.com
}

\begin{abstract}
Abstrak:
Salah satu faktor penunjang dan keberhasilan kunci sekolah yang memiliki prestasi atau kesuksesan adalah faktor kepemimpinan atau manajemen kepala sekolah. Oleh karena itu, peneliti berusaha untuk mengungkap keberadaan tokoh sentral kepala sekolah, dalam melakukan perubahan, perubahan manajemen dan perubahan baru bagi para guru, karena kepala sekolah merupakan tokoh yang paling dominan dalam meningkatkan profesionalisme guru dan institusi pendidikan menjadi lebih maju Hasil penelitian menunjukkan bahwa: (1) perencanaan kepala sekolah dalam meningkatkan profesionalisme guru, pertama, kepala sekolah mengacu pada visi, misi dan tujuan sekolah dalam meningkatkan profesionalisme guru, kedua, kepala sekolah mengembangkan dan memotivasi para guru dan bawahannya dalam meningkatkan profesionalisme guru, (2) Penerapan tugas kepala sekolah dalam meningkatkan profesionalisme guru: pertama, kepala sekolah meningkatkan pengawasan dalam meningkatkan profesionalisme guru, kedua, kepala sekolah menjadikan guru sebagai mitra, dalam mengambil keputusan. , pengaturan job description, pembuatan promissory, prota, dan perencanaan persiapan belajar. (3) Evaluasi kepala sekolah dalam meningkatkan profesionalisme guru, pertama, kepala sekolah memberi penghargaan kepada guru yang berprestasi, kedua, kepala sekolah memberi posisi kepada guru yang mampu menempati posisi strategis, seperti wakil kepala sekolah, ketua dari panitia, dan kelas wali.
\end{abstract}

Kata Kunci: Manajemen, Kepala Sekolah, Guru Profesional

\begin{abstract}
:
One of supporting factors and success key for school which has an achievement or success is a factor of leadership or head master's management. Therefore, researchers are trying to uncover the existence of the central figure of the headmaster, in making changes,
\end{abstract}


management changes and a new changing for the teachers, because the head master is the most dominant figure in improving the professionalism of teachers and educational institutions to be more advanced. The results shows that: (1) the head master's planning in improving teacher professionalism, first, the head master refers to the vision, mission and goals of the school in improving the professionalism of teachers, second, the head master develop and motivate the teachers and his subordinates in improving the professionalism of teachers, (2) Implementation of head master's job in improving teacher Professionalism: first, head master improve the supervision in improving the professionalism of teachers, second, head master make the teachers as partners, in making decision, arrangement of job description, making the promissory, prota, and the planning of learning preparation. (3) Head master's evaluation in improving teacher Professionalism, first, head master gives reward to the teachers who has achievement, second, head master gives position to teachers who are able to occupy in the strategic positions, such as vice of head master, chairman of the committee, and guardian class.

Keywords: Management, Head Master, Teacher Professionalism.

\section{Pendahuluan}

Salah satu isu penting dalam penyelenggaraan pendidikan saat ini adalah masalah peningkatan mutu pendidikan, salah satu faktor pendukung dan kunci keberhasilan bagi sekolah berprestasi atau sukses adalah faktor kepemimpinan atau manajemen kepala sekolah. Krisis multi dimensi yang dialami bangsa Indonesia belum sepenuhnya teratasi sehingga memberikan dampak negatif terhadap dunia pendidikan dengan memunculkan keseimbangan baru pendidikan. Pendidikan dewasa ini menghadapi berbagai tantangan dan persoalan misalnya; 1). Bertumbuhnya jumlah penduduk yang sangat cepat dan sekaligus bertambahnya keinginan masyarakat untuk mendapatkan pendidikan, yang secara kumulatif menuntut tersedianya sarana pendidikan yang memadai, (2) berkembangnya ilmu pengetahuan yang modern menghendaki dasar-dasar pendidikan yang kokoh dan penguasaan kemampuan terus-menerus, dan dengan demikian menuntut pendidikan yang lebih lama sesuai dengan konsep pendidikan seumur hidup, (3) berkembangnya teknologi yang mempermudah manusia dalam menguasai dan memanfaatkan alam dan lingkungan, tetapi yang 
sering kali ditangani sebagai suatu ancaman terhadap kelestarian peranan manusia. ${ }^{1}$

Pendidikan yang merupakan salah satu pilar kehidupan bangsa. masa depan suatu bangsa bisa diketahui melalui sejauh mana komitmen masyarakat, bangsa atau Negara dalam menyelenggarakan pendidikan nasional. Oleh karena itu, pendidikan menjadi faktor utama atau penentu bagi masa depan bangsa. Dalam rangka perwujudan fungsi idealnya untuk peningkatan kualitas sumber daya manusia tersebut, sistem pendidikan di Indonesia haruslah senantiasa mengorientasikan diri menjawab kebutuhan dan tantangan yang muncul dalam masyarakat Indonesia sebagai konsekuensi logis perubahan.

Sekolah adalah merupakan suatu lembaga pendidikan formal yang menyelenggarakan kegiatan proses belajar mengajar sebagai upaya untuk tercapainya tujuan pendidikan. Penanggung jawab dalam proses belajar mengajar yang dilakukan di sekolah ditentukan pula bagaimana profesionalisme guru. Tinggi rendahnya mutu pendidikan banyak dipengaruhi oleh kualitas proses pembelajaran yang dilakukan oleh guru, karena guru secara langsung memberikan bimbingan dan bantuan kepada siswa dalam upaya mencapai tujuan pendidikan.

Guru sebagai pendidik merupakan tenaga profesional yang bertugas merencanakan dan melaksanakan proses pembelajaran, menilai pembelajaran, melakukan bimbingan dan pelatihan, serta melakukan penelitian dan pengabdian kepada masyarakat. Oleh karena itu, para guru wajib mengembangkan kemampuan profesionalnya agar dapat meningkatkan kinerja dalam melaksanakan tugas, karena pendidikan di masa yang akan datang menuntut keterampilan profesi pendidikan yang bermutu. ${ }^{2}$ Guru sebagai tenaga profesional yang merupakan faktor penentu mutu pendidikan harus memiliki keterampilan manajemen disekolah dan juga harus berperan sebagai pengembang budaya belajar siswa.

Untuk itu, karena guru adalah tenaga profesional, mereka harus terdidik dan terlatih secara akademik dan profesional serta mendapat pengakuan formal sebagaimana mestinya ${ }^{3}$, dan profesi mengajar harus memiliki status profesi yang membutuhkan

\footnotetext{
${ }^{1}$ Udin Saefudin Sa'ud, Inovasi Pendidikan, (Bandung, Alfabeta, 2008), 5.

2 Ibid, 5.

${ }^{3}$ Depdiknas, Rencana Strategis Depdiknas, (Jakarta: Depdiknas, 2005)
} 
pengembangan. ${ }^{4}$ Guru sebagai tenaga profesional harus memenuhi beberapa kriteria, yaitu: (1) mempunyai komitmen terhadap siswa dan proses belajar, (2) menguasai mata pelajaran yang diajarkan serta cara mengajarnya kepada siswa, (3) bertanggung jawab memantau hasil belajar siswa melalui berbagai cara evaluasi, dan (4) mampu berfikir sistematis tentang apa yang dilakukannya dan belajar dari lingkungan profesinya. ${ }^{5}$

Mengingat guru sebagai ujung tombak yang tidak terlepas dari kekurangan dan kelebihannya, peranan kepala sekolah sebagai manajer dalam sebuah lembaga pendidikan bertanggung jawab dalam membina bawahannya untuk mencapai tujuan yang diharapkan. Sesuai dengan visi dan misi yang telah ditetapkan. Terutama dalam meningkatkan profesionalisme guru dalam membimbing dan mengarahkan siswa menjadi manusia yang berkualitas dan patut dibanggakan.

Untuk tujuan tersebut diatas, menumbuhkan profesionalisme guru dalam sebuah lembaga pendidikan adalah kerja keras kepala sekolah. Seorang pemimpin pendidikan merupakan senteral dari kegiatan yang diprogramkan. Pemimpin merupakan decision maker dan juga teladan bagi anak buahnya. Karena itu seorang pemimpin setidaknya dapat memberikan contoh yang baik kepada anak buahnya. Sebagai pembuat keputusan dan penentu kebijakan, seorang pemimpin harus memiliki satu aspek yang memiliki peran yang sangat penting dalam memimpin organisasi bersangkutan. ${ }^{6}$

Oleh karena itu, semua kegiatan sekolah perlu diawasi untuk mengetahui apakah program pendidikan nasional yang dilakukan di sekolah berjalan sebagaimana mestinya ataukah tidak. Pada dasarnya sekolah yang bermutu baik dikarenakan semua sistem pengelolaan administrasinya yang menjadi tugas sekolah dapat berjalan dengan efektif dan guru-guru dapat melaksanakan tugasnya dengan penuh tanggung jawab sebagaimna dinyatakan oleh American Association of School Administration, "It is generally agreed that school will be better if teacher are better prepared, better served and better paid". ${ }^{7}$

Kepala sekolah merupakan top manajemen yang mengatur aktivitas program kerja sekolah menjadi terarah, terfokus, dan

\footnotetext{
${ }^{4}$ H.A.R. Tilaar, Manajemen Pendidikan Nasional, (Bandung: Remaja Rosdakarya, 2001), 142.

${ }^{5}$ H. Hasan, Guru yang Profesional, (Bandung: UPI, 2003), 5.

${ }^{6}$ Muhamd Saroni, Manajemen Sekolah, (Yogyakarta: Ar-Ruzz Media, 2006), 15.

${ }^{7}$ Dadang Suhardana, Supervisi Profesional Layanan dalam Meningkatkan Mutu Pembelajaran di Era Otonomi Daerah, (Bandung: Alfabeta, 2010), 83.
} 
mengalami peningkatan yang signifikan. Oleh karena itu, kepala sekolah berperan penting bagi peningkatan mutu pendidikan dan profesionalisme guru untuk lebih semangat dan profesional dalam mengajar mengembangkan diri dalam mentransfer ilmu pengetahuan kepada peserta didik.

Kepala sekolah sebagai pimpinan lembaga memiliki pengaruh dan peranan yang sangat besar bagi peningkatan kemajuan sekolah. Di sisi lain kepala sekolah juga berperan penting bagi peningkatan kualitas guru untuk lebih semangat dan profesional dalam mengajar. Dengan alasan yang sangat mendasar bahwa guru memiliki peran yang sangat penting dalam menentukan kualitas pengajaran yang dilaksanakan. Hal ini menunjukkan bahwa guru diharapkan mampu berperan aktif sebagai pengelola proses belajar mengajar, bertindak sebagai fasilitator yang berusaha menciptakan organisasi kelas, pengguna metode mengajar maupun sikap dan karakteristik guru dalam mengelola belajar mengajar. ${ }^{8}$

Perangkat sekolah seperti kepala sekolah, dewan guru, siswa, pegawai atau karyawan harus saling mendukukung untuk bekerja sama mencapai tujuan yang telah ditetapkan. Oleh karena itu dapat dikatakan bahwa sukses atau tidaknya suatu organisasi dalam mencapai tujuan yang telah ditentukan sangat tergantung atas kemampuan pimpinannya untuk menumbuhkan iklim kerja sama agar dengan mudah dapat menggerakkan sumber daya manusia yang ada, sehingga pendayagunaannya dapat berjalan dengan efektif dan efisien.

Oleh sebab itu, Kepala sekolah sebagai penanggung jawab dan sekaligus pengelola pendidikan, harus mampu mengawasi sekolah secara keseluruhan. Salah satu diantaranya adalah mengawasi profesionalisme guru dan kinerja guru dalam melaksanakan proses belajar mengajar di kelas. Guru merupakan sumber daya manusia yang dalam proses belajar mengajar perlu di kontrol kinerjanya dalam melakukan proses pembelajaran dikelas. Maka dari itu, Peranan kepala sekolah dalam meningkatkan profesionalisme dan kinerja guru di sekolah sangat besar, karena kepala sekolah sebagai manajerial sekaligus yang memiliki tanggung jawab dalam meningkatkan etos kerja dan motivasi kerja para guru di sekolah. SMAN 2 Bangkalan merupakan lembaga pendidikan yang memiliki visi Mewujudkan generasi yang berprestasi, cerdas, kreatif, dan memiliki jiwa kewirausahaan serta menjungjung tinggi

${ }^{8}$ Cece Wijaya, dkk, Kemampuan dasar dalam Proses Belajar Mengajar, (Bandung: PT. Remaja Rosdakarya, 1999), 2. 
nasionalisme dengan berpijak pada akhlak yang mulia. Sementara misi SMAN 2 Bangkalan diantaranya meningkatkan lingkungan pembelajaran yang kondusif dalam upaya meningkatkan mutu pembelajaran, dan meningkatkan kualifikasi tanaga kependidikan sesuai dengan tuntutan pembelajaran yang berkualitas ${ }^{9}$. Untuk mewujudkan generasi yang berprestasi tentunya tidak hanya didukung dengan media pembelajaran yang baik, tetapi juga harus di bina oleh guru yang profesional. Untuk mewujudkan itu semua di butuhkan manajer atau pemimpin yang mampu memenej dan melakukan pembinaan terhadap bawahan, baik kepada para guru, staf, karyawan dan terlebih pada peserta didik ${ }^{10}$.

Jika di lihat secara fisik SMAN 2 Bangkalan adalah merupakan lembaga pendidikan yang bisa dikatakan baik, sarana prasarana (fisik gedung, kelas, laboratorium dan media lainnya), sementara dari segi kualitas dan kwantitas lembaga ini telah terakreditasi dengan nilai A dengan nomor SK: 4/5/BASDA-P/2005 dan memiliki peserta didik cukup banyak, dengan total 927 dengan perincian: 460 siswa putra dan 467 siswa putri. Dan memiliki prestasi baik secara akademik dan non akademik, berprestasi dalam bidang akademik berupa kompetisi olimpiade science fisika dan matematika, sedangkan dari sisi non akademik berupa kacong jebbing, PMR, KIR, Pencita Alam, Pramuka, Keagamaan dan kegiatan ekstrakurikuler yang lainnya, yang paling menunjol bahwa lembaga ini menjadi lembaga pilihan masyarakat dalam mendidikkan putra dan putrinya.

Sejalan dengan diatas, secara institusional, SMAN 2 Bangkalan adalah merupakan lembaga pendidikan yang berlebel RSBI sebelum dikeluarkannya putusan Mahkamah Konstitusi terkait pembubaran status RSBI yang disenyalir terjadi liberalisasi pendidikan, dan terdapat 68 orang pendidik dan 20 orang tenaga kependidikan yang mengelola dan bertanggung jawab dalam proses belajar mengajar. Untuk mengelola proses belajar mengajar yang baik dan untuk menjadi lembaga yang berkualitas dibutuhkan pemimpin yang memiliki manajemen yang baik, mulai dari konsep perencanaan, pengorganisasian, menggerakkan dan pengawasan. Empat komponen tersebut akan berjalan dengan baik jika ada kerjasama

\footnotetext{
${ }^{9}$ Data diperoleh dari profil sekolah SMAN 2 Bangkalan, tanggal 16 Maret 2013.

10 Wawancara dengan Ibnu Harijanto waka sarpras SMAN 2 Bangkalan pada tanggal 20 Maret 2013.
} 
yang baik pula antara pimpinan sekolah dengan tenaga pendidik juga stakeholder yang ada di lembaga tersebut. ${ }^{11}$

\section{Metode Penelitian}

Berdasarkan, fokus penelitian, obyek penelitian, maupun sumber data yang akan dikumpulkan,12 terkait perencanaan, pelaksanaan kerja dan evaluasi kepala sekolah dalam meningkatkan profesionalisme guru di SMAN 2 Bangkalan, maka dari itu metode yang digunakan dalam penelitian adalah metode kualitatif dengan jenis studi kasus. Adapun tujuan studi kasus adalah untuk memberikan gambaran secara mendetail tentang latar belakang, sifat-sifat, karakter yang khas dari kasus ataupun status dari individu, yang kemudian dari sifat-sifat diatas akan dijadikan suatu hal yang bersifat umum. ${ }^{13}$ Dalam penelitian studi kasus yang ditekankan adalah pemahaman tentang mengapa subjek tersebut melakukan demikian dan bagaimana perilaku berubah ketika subjek memberikan tanggapan terhadap lingkungan dengan menemukan variable penting sejarah perkembangan subjek.

Dengan demikian diketahui bahwa pendekatan yang digunakan dalam penelitian ini adalah pendekatan kualitatif, sebab dalam melakukan tindakan kepada subyek adalah untuk mengungkapkan makna dari manajemen kepala sekolah dalam meningkatkan profesionalisme guru di Sekolah Menengah Atas Negeri 2 yang berada di Bangkalan.

Berdasarkan paparan di atas dapat dikatakan bahwa Penelitian kualitatif mempunyai karakteristik pokok mementingkan makna, konteks, proses penelitiannya lebih bersifat siklus dari pada linier. Pengumpulan dan analisa data berlangsung secara simultan. Lebih mementingkan kedalaman ketimbang keluasan penelitian.

Penelitian dengan pendekatan kualitatif disebut juga dengan penelitian naturalistik. Penelitian naturalistik pada hakikatnya mengamati orang dalam lingkungan hidupnya, berinteraksi dengan mereka, serta berusaha memahami tuturan dan penafsiran mereka tentang dunianya. Untuk itu perlu diamati lingkungan yang melatar belakangi kehidupan orang tersebut. Dengan pendekatan ini, dapat teramati keutuhan dan kealamiannya.

\footnotetext{
11 Wawancara dengan Abu Husnul Harkan kepala sekolah SMAN 2 Bangkalan, pada tanggal 16 Maret 2013.

12 Kartini Kartono, Pengantar Metodologi Riset Sosial. Bandung; Mandar Maju, 1996). 47.

${ }^{13}$ Moh. Nasir, Metode penelitian, (Jakarta: Ghlmia Indonesia, 2003), 55.
} 
Dalam penelitian ini peneliti menggunakan tindakan kalaboratif partisipatoris, yaitu peneliti bekerja sama dengan guru dan kepala sekolah/madrasah serta serta warga sekolah yang terkait, termasuk di sini komite. Dalam hal ini peneliti terjun langsung dalam merencanakan, mengindentifikasi masalah sampai ber-akhirnya penelitian ini.

Oleh karena itu sesuai dengan fokus dalam penelitian ini, maka penelitian ini berupaya untuk mengetahui dan menelaah tentang "implementasi manajamen kepala sekolah dalam meningkatkan profesionalisme guru" Pendekatan yang digunakan dalam penelitian ini adalah pendekatakan kualitatif.

Dalam penelitian ini, peneliti mengamati individu atau unit secara, mendalam dan mencari faktor-faktor yang dapat menjelaskan kondisi subyek dan obyek yang diteliti. Penelitian kualitatif lebih menghendaki arah bimbingan penyusunan teori subyektif yang berdasarkan data, baik melalui observasi, wawancara dan dokumentasi. Jadi penelitian ini bertujuan untuk menyajikan uraian deskriptif tentang bagaimana implemenatasi manajemen kepala sekolah dalam meningkatkan profesionalisme guru di SMA Negeri 2 Bangkalan.

Tempat penelitian sebagai latar belakang untuk memperoleh data yang berguna untuk mendukung tercapainya tujuan penelitian ini, peneliti melakukan penelitian di SMAN 2 Bangkalan, dilihat dari kelembagaan, lembaga ini telah terakreditasi dengan nilai A dengan nomor SK: 4/5/BASDA-P/2005 dan menjadi lembaga pendidikan pilihan masyarakat dalam mendidikkan putra-putrinya, memiliki kualitas secara akademik dan non akademik. Dari segi manajemen sarana prasarana bisa dikatakan sudah memenuhi standart dalam melakukan proses belajar mengajar. Juga letaknya sangat strategis karena mudah dijangkau oleh masyarakat, kendaraan umum dan tidak jauh dari pusat kota kabupaten Bangkalan. 


\section{Pembahasan dan Hasil Penelitian \\ Perencanaan Kepala Sekolah dalam Meningkatkan Profesionalisme Guru}

Perencanaan kepala sekolah dalam meningkatkan dalam meningkatkan profesionalisme guru SMA Negeri 2 Bangkalan, mengacu pada visi, misi dan tujuan sekolah. Hal ini sangat penting mengingat rumusan visi akan menjadi dasar rumusan misi sekolah, misi menjadi dasar perumusan tujuan, sementara tujuan menjadi dasar perumusan sasaran yang ingin dicapai oleh sekolah dimasa depan. Nilai masa depan hendaknya sekolah diupayakan agar mengantisipasi masa depan yang lebih baik karena mengelola lembaga pendidikan sama artinya mengelola menyiapkan generasi yang akan hidup menghadapi tantangan-tantngan masa depan yang jauh berbeda dengan masa sebelumnya. Maka seseorang dituntut untuk memiliki dinamika yang tinggi, komitmen terhadap masa depan, dan memiliki kepekaan terhadap perkembangan masyarakat serta ilmu pengetahuan. Selanjutnya perencanaan kepala sekolah dalam meningkatkan profesionalisme guru di SMA Negeri 2 Bangkalan berdasarkan temuan peniliti dilapangan Kepala sekolah memberikan pembinaan, motivasi pada guru dalam meningkatkan profesionalisme guru.

Sebagaimana pendapat Segiovani dan Elliot; kepala sekolah memiliki dua fungsi utama bagi sekolah yang dikelolanya, pertama kepala sekolah sebagai administrator, kepala sekolah bertugas melaksanakan fungsi-fungsi administrasi pendidikan, kedua, kepala sebagai Edukator dalam hal ini kepala sekolah melaksanakan fungsi edukatif. ${ }^{14}$ Artinya merupakan kegiatan yang mengarahkan dan membina setiap tenaga pendidik dalam melaksanakan tugas dan pengajaran secara tepat dan benar.

Kepemimpinan kepala SMA Negeri 2 Bangkalan, adalah berorientasi pada hubungan dengan para guru dengan memberi pembinaan, dorogan dan semangat, dan merujuk dari konsep dan pemahaman kepemimpinan yang dilontarkan oleh pakar manajemen Koontz dan kawan-kawan mendefinisikan bahwa : leadership is generally definet simplyas influence, the art of process of influencing people so that they will strive willingly toward the achievement of group goals (kepemimpinan secara umum merupakan pengaruh, seni atau proses mengetahui orang lain,

14 Marno, Triyo supriyatno, Manajemen dan Kepemimpinan Pendidikan Islam, (Bandung: Refika Aditama, 2008), 35 
sehingga mereka dengan penuh kemauan berusaha ke arah tercapainya tujuan organisasi). ${ }^{15}$

Dari konsep tersebut dapat ditarik lebih jauh tentang makna yang terkandung di dalamnya. Makna kata penuh kemauan berusaha, mencerminkan keinginan keras dengan penuh semangat dan percaya diri. Arti kata "semangat" sebenarnya di dalamnya tercermin hasrat, kesungguhan, intensitas dalam melaksanakan pekerjaan. Demikian pula di dalam kata percaya diri merefleksikan pengalaman dan kemampuan teknis.

Kepala sekolah SMA Negeri 2 Bangkalan dalam meningkatkan profesionalisme dan kinerja guru selalu :

1) Memberikan pembinaan, pelatihan dan mengarahkan para guru, staf serta memberikan motivasi untuk memacu keratif, inovatif demi kemajuan dan memberikan inspirasi dalam mencapai tujuan.

2) Mendorong timbulnya kamauan yang kuat dengan penuh semangat dan percaya diri para guru, staf dalam melaksanakan tugas masing-masing.

3) Menghindarkan diri dari sikap memaksakan pendapat atau bertindak keras terhadap guru, dan staf. Kepala sekolah harus mampu melakukan perbuatan yang membangkitkan ghiroh dan semangat para guru, dan staf, dan untuk bekerja dengan profesionalitas, kreatif, inovatif dan percaya diri.

Kepala sekolah sebagai manajer disekolah memegang peranan yang menentukan dalam mencapai tujuan organisasi sekolah. Kepala sekolah top manajer sekolah, harus dapat menerapkan manajemen, kepemimpnan administrasi yang efektif dalam memberikan layanan, pembinan kepada guru dan personil sekolah lainnya. Dengan menajmen atau kepemimpinan administrative yang efektif, kepala sekolah dapat menumbuhkan, memelihara, dan mengembangkan usaha, dan iklim koperatif dalam kehidupan organisasi dan dalam memberikan layanan kepada guru untuk meningkatkan motivasi kerja, kinerja, dan hsil pembelajaran di kelas, dengan demikian diharapkan memacu peningkatan profesionalisme guru sehingga berdampak positip terhadap lembaga pendidikan tersebut.

Selain layanan, pembinaan, pelatihan dan lain sebaginya, kepala sekolah berkontribusi signifikan terhadap profesionalisme guru dan kinerja guru, baik secara sendiri-sendiri maupun secara bersama-sama, hal ini sebagaimana dikutip oleh Wahjosumidjo,

${ }^{15}$ Sulistyorini.. Manajemen pendidikan Islam. (Surabaya: el.KAF. 2006), 134.

Badrut Tamam Manajemen Head Master 
berbagai hasil penelitian menyimpulkan bahwa layanan, supervisi pengajaran, pembinan, dan pelatihan yang diberikan oleh kepala sekolah sebagai manajer organisasi sekolah dan sebagai supervisor kepada guru dapat meninkatkan motivasi guru dan kinerja di sekolah. ${ }^{16}$

Dalam bab sebelumnya dijelaskan bahwa upaya peningkatan profesionalisme guru, sebagaimana yang dikatakan Djabar lima pola pendekatan, pertama, peningkatan disiplin kerja, kedua, peningkatan kualitas kerja, ketiga, peningkatan disiplin belajar menggajar, keempat, peningkatan mutu proses belajar mengajar, dan kelima, peningkatan pengawasan.

Bertolak dari pernyataan diatas, kepala sekolah sebagai top manajemen dalam lembaga pendidikan memiliki kontribusi layanan terhadap bawahan dalam meningkatkan profesionalisme guru hal tersebut dapat ditinggkatkan melalui layanan pengawasan kepala sekolah, hal ini senada apa yang dikatakan oleh Dangkua yang menyimpulkan bahwa sekitar 35-40\% kinerja profesional guru di sekolah dapat ditingkatkan melalui layanan supervisi atau pengawasan dari kepala sekolah, dan selebihnya bisa ditingkatkan oleh guru sendiri. ${ }^{17}$ Ini artinya bahwa kepala sekolah sebagai manajer dan pemimpin memiliki kontribusi terhadap peningkatan kinerja profesional guru.

Untuk meraih kesuksesan itu, kepala sekolah selalu memberikan motivasi dengan salah satu cara adalah meningkatkan kesejahteraan para guru dan bawahan dengan adil dan merata. Untuk mewujudkan cita-cita dan keberhasilan sekolah harus juga disertai dengan pengorbanan, salah satunya adalah usaha untuk meningkatkan kesejahteraan secara adil, dan kepala sekolah berusaha untuk balance antara kerja keras para guru dan bawahannya, diantaranya seperti, penerimaan insentif setiap bulan, tunjangan hari raya, pengadaan rekreasi setiap tahun.

Dalam pendapat Fred Luthans ada tiga unsur dari motivasi yakni kebutuhan (need), dorongan (drive), dan tujuan (goals). ${ }^{18}$ Dari pendapat tersebut jelas bahwa motivasi sangat dibutuhkan untuk mencapai tujuan terutama dalam kualitas sumberdaya manusia.

\footnotetext{
16 Wahjosumidjo, Kepemimpinan Kepala Sekolah, (Jakarta: RajaGrafindo Persada, 1994), 12

17 Abdul Hadis, Nurhayati, Manajemen Mutu Pendidikan, (Bandung: Alfabeta,2010), 62

18 Miftah Thoha, Perilaku Organisasi Konsep Dasar dan Aplikasinya, (Jakarta: PT RajaGafindo Persada, 2010), 207.
} 
Kepala sekolah sebagai pimpinan lembaga tentunya dalam memotivasi para guru selalu menginformasikan setiap ada permasalahan dan menganggap guru sebagai mitra kerja, dalam membuat keputusan-keputusan bersama, baik penyusunan program kerja sekolah, berupa pembuatan program semester, program tahunan, RPP, dan perangkat mengajar. Dengan kekuatan motivasi itu sendiri menyebabkan seseorang berusaha mencapai tujuan.

Disisi lain kepala sekolah sebagai pimpinan, pengawas, penanggung jawab juga sebagai teman dan mitra dalam melaksanakan program-program atauapun melibatkan para guru di dalam pengambilan keputusan, Wuradji mengkategorikan empat model kepemimpinan yang dapat dipilih oleh seorang kepala sekolah, yaitu : pertama structural leadership; kedua facilitative leadership; ketiga suportive leadership; keempat participative leadership ${ }^{19}$

Dan kepala SMA Negeri 2 Bangkalan yang mengangap guru sebagai mitra kerja termasuk kategori model keempat yaitu participative leadership, karena kepala sekolah:

1. Lebih mengutamakan kerja kelompok, disamping tetap memberikan kesempatan untuk bekerja secara mandiri.

2. Melibatkan pihak lain dalam pengambilan keputusan.

3. Mempertahankan kemauan dan semangat kebersaman.

4. Mempertahankan dan melestarikan kesediaan dan komitmen anggota untuk berpartisipasi dalam semua urusan organisasi.

Guru merupakan ujung tombak dalam mencapai keberhasilan anak didiknya, dan merupakan pelaku utama yang harus senantiasa ditingkatkan kompetensinya, untuk itu salah satu cara kepala sekolah SMA Negeri 2 Bangkalan, menganggap para guru sebagai mitra kerja secara bersama berjuang dan bertanggung jawab untuk memajukan sekolah, dan tidak ada perbedaan antara kepala sekolah dengan bawahannya yang membedakan hanyalah tanggung jawab masing-masing guru, dan bawahan, sehingga dengan cara seperti itu akan membangkitkan semangat kerja guru, maka dengan semangat kerja itulah usaha peningkatan kompetensi guru akan lebih leluasa, yang pada akhirnya profesionalisme guru itu meningkat dengan sendirinya, dan ini akan berpengaruh terhadap pencapaian kualitas, baik dari segi guru itu sendiri dan juga pada lembaga pendidikan.

Kepala sekolah SMA Negeri 2 Bangkalan setiap akan melaksanakan kebijakan ataupun keputusan, selalu berkonsultasi

19 Wuradji.. The Educational Leadership, Kepemimpinan Transformasional. (Yogyakarta: Gama Media, 2008) 99. 
dengan para guru dan bawahan lainnya, sebelum keputusan itu diberlakukan, bahkan dengan hati-hatinya kepala sekolah dalam kesempatan setiap rapat, mengutarakan dan mensosialisasikan dampak yang timbul jika kebijakan itu dilaksanakan, karena kebijakan maupun keputusan itu semata-mata untuk tujuan bersama dan kebaikan bersama pula.

Hal ini senada dengan yang dikatakan Nawawi, setiap pemimpin harus mampu bekerja sama dengan orang-orang yang dipimpinya untuk memberikan motivasi agar melakukan pekerjaan dengan ihklas ${ }^{20}$, karena pada prinsipnya kepala sekolah, ketika membuat kebijakan atau keputusan akan didukung oleh para guru atau bawahan, sehingga akan berpengaruh terhadap kinerja para guru dan bawahan, dan menimalisir rasa malas guru dalam mengajar, mangkir dalam tugas, tertundanya pekerjaan.

Kepala sekolah SMA Negeri 2 Bangkalan dalam meningkatkan profesionalisme guru, menjadikan para guru dan bawahan sebagai mitra kerja dan memotivasi bawahan. Komaruddin mengatakan motivasi adalah keseluruhan proses gerakan yang mendorong perilaku untuk mencapai tujua. ${ }^{21}$ Dengan memberikan motivasi pada guru, menginformasikan dan membicarakan bersama-sama dengan guru, maka kebijakan yang akan diterapkan kepada para guru itu akan dijalankan sebaik-baiknya, yang pada akhirnya akan meningkatkan profesionalisme dan kompetensi guru.

\section{Pelaksanaan Kerja Kepala Sekolah dalam Meningkatkan Profesionalisme Guru.}

Kepala sekolah sebagai pemimpin dan manajer dalam lembaga bertanggung jawab dalam meningkatkan sumber daya manusia yang ada di lembaga ia pimpin. Berdasarkan hasil temuan peneliti, bahwa evaluasi kepala sekolah dalam meningkatkan profesionalisme guru di SMA Negeri 2 Bangkalan, adalah kepala sekolah mengadakan supervisi, memberikan bimbingan dan pelatihan terhadap para guru terutama wali kelas dalam hal perkembangan anak asuhannya, dan program-program yang sudah ditentukan.

Diantara peran dan fungsi kepemimpinan kepala sekolah adalah kepala sekolah sebagai supervisor. Supervisi sebagai salah

\footnotetext{
20 Marno, Triyo Supriyatno, Manajemen dan Kepemimpinan Pendidikan Islam, (Bandung: PT Refika Aditama, 2008), 33

${ }^{21}$ Mulyadi, Kepemimpinan Kepala Sekolah dalam Mengembangkan Budaya Mutu, (Malang: UIN Maliki Pres, 2010). 56
} 
satu fungsi pokok dalam administrasi pendidikan, bukan hanya merupakan tugas pekerjaan para pengawas pendidikan pada umumnya, tetapi juga tugas seorang kepala sekolah terhadap peningkatan kerja bawahannya yaitu para guru, staf dan pegawai lainnya, yang implikasinya akan meningkatkan kualitas belajar mengajar di kelas, sehingga akan melahirkan siswa-siswa yang bermutu. Oleh karenanya kepala sekolah sebagai supervisor hendaknya pandai meneliti, mencari dan menentukan syara-syarat mana yang diperlukan bagi kemajuan sekolahnya sehingga tujuan pendidikan di sekolah itu tercapai dengan maksimal.

Tugas kepala sekolah sebagai supervisor sangat penting, karena justru bidang inilah faktor yang strategis untuk keberhasilan program-program dan tujuan sekolah, sesuai dengan uraian James A.F Stoner, kepala sekolah juga sebagai manajer, pada hakekatnya adalah seorang perencana, organisator, pemimpin dan pengendali ${ }^{22}$, keberadaan manajer dalam suatu organisasi sangat diperlukan, sebab organisasi sebagai alat mencapai tujuan organisasi dimana di dalamnya berkembang berbagai macam pengetahuan, serta organisasi menjadi tempat untuk membina dan mengembangkan karir dan potensi sumber daya manusia, itu semua memerlukan seorang manajer yang mumpuni yang mampu untuk merencanakan, mengorganisasikan, memimpin dan mengendalikan.

Kepala sekolah mengadakan supervisi, dan kegiatan supervisi ini juga salah satu rangkaian dari memantau dan memeriksa. Supervisi dilaksanakan terhadap pekerjaan dan tugas guru sebagai tenaga pengajar, baik dilaksanakan dengan cara terjadwal, maupun dilaksanakan secara mendadak di kelas, manakala dari hasil supervisi itu ditemukan kesalahan atau membuat anak gaduh di kelas, maka kepala sekolah memanggil guru yang bersangkutan di ruang kepala sekolah, dari tindak lanjut supervisi itu selanjutnya kepala sekolah memberikan bimbingan-bimbingan dan nasihatnasihat. Dengan cara seperti itu lambat laun akan terjadi peningkatan terhadap kinerja guru.

Sebagaimana konsep yang dikembangkan oleh Koontz, kepala sekolah sebagai seorang pemimpin harus mampu :

a. Mendorong timbulnya kemauan yang kuat dengan penuh semangat dan percaya diri para guru dan bawahan dalam melaksanakan tugas msing-masing.

b. Memberikan bimbingan dan mengarahkan para guru dan bawahan serta memberikan dorongan memacu dan berdiri di

\footnotetext{
22 Wahjosumijo. Tinjauan, (tinjauan teoritik dan permasalahan) Kepemimpinan Kepala sekolah. (Jakarta: Raja Grafindo Persada, 1999), 96.
} 
depan demi kemajuan dan memberikan inspirasi sekolah dalam mencapai tujuan.

Dalam pelaksanaan pengawasan atau supervisi, cara yang digunakan yaitu kepala sekolah menanyakan langsung kepada para guru dan khususnya para wali kelas, karena wali kelas, merupakan ujung tombak dalam pembinaan dan keberhasilan masing-masing rombongan belajar. Kepala sekolah menanyakan langsung kepada wali kelas tentang perkembangan anak yang diampunya, bahkan walau sudah memeriksa bukti-bukti atau dokumen-dokumen terhadap masing-masing keberadaan siswa, kepala sekolah juga masih mengadakan kroscek dengan pihak BP, karena BP telah memiliki data sendiri, setiap hari pihak BP mengabsen kehadiran siswa di kelas sekaligus memantau keadaan riil di kelas masingmasing, dan berkenaan dengan evaluasi dan monitoring ini, kepala sekolah SMA Negeri 2 Bangkalan setiap hari senin memeriksa presensi khusus guru dan karyawan.

Hal ini senada dengan pendapat Sargiovanni menegaskan tujuan supervisi terutama dalam pembelajaran yaitu; meningkatkan efektivitas dan efesiensi pembelajaran, pengawasan kualitas, dan pengembangan profesional. ${ }^{23}$ Kepala sekolah sebagai supervisor memainkan peran penting dalam meningkatkan profesionalisme guru, juga karyawan, dan peserta didik.

Dalam soal membimbing para guru dan bawahannya, kepala sekolah menunjukkan ada usaha untuk membimbing dan memberi nasihat-nasihat yang tujuannya juga meningkatkan kualitas dan kompetensi guru, dan melakukan hal-hal yang membantu untuk mendapatkan keterampilan seseorang. Dengan adanya supervisi sekaligus bimbingan yang telah diprogramkan dan di jadwal oleh kepala sekolah, adalah juga merupakan rangkaian dari usaha peningkatan kompetensi guru dalam soal kegiatan belajar mengajar, jadi kepala sekolah betul-betul mengusahakan agar para guru lebih profesional dalam merencanakan, pembuatan RPP, mengajar di kelas, dan mengevalusi. Bahkan dalam rangka peningkatan kompetensi guru, kepala sekolah berusaha semaksimal mungkin memberikan yang terbaik kepda para guru dan staf, dalam pembelajaran setiap guru menggunakan proyektor supaya proses pembelajaran lebih efektif dan efisien, sehingga pembelajaran menjadi menyenangkan.

23 Mukhtar, Iskandar, Orientasi Baru supervisi Pendidikan, (Jakarta: Gaung Persada, 2009), 53 
Kepala sekolah menjadikan guru sebagai mitra kerja, dalam membuat kebijakan dan keputusan bersama, dalam penyusunan perangkat pembelajaran. Kepala sekolah memberi kepercayaan, dan kerja kelompok kepada para guru yang dianggap mampu untuk menduduki jabatan-jabatan, seperti wakil kepala sekolah, wali kelas dan kepanitiaan, maupun dalam melaksanakan pembelajaran di kelas.

Dalam melaksanakan tugas dan program kerja, kepala sekolah selalu menciptakan kebersamaan, memberi kepercayaan serta berusaha membagi tugas, sesuai dengan taksonomi yang dikemukakan Gary Yukl, menyatakan ada tiga dimensi yaitu: perhatian terhadap efisiensi tugas, hubungan manusia, dan perubahan adaptif. Sedangkan kepala SMA Negeri 2 Bangkalan adalah kategori dimensi hubungan manusia, jenis perilaku kepemimpinan seperti ini terutama memperhatikan perbaikan hubungan dan membantu orang, meningkatkan kooperasi dan kerja tim, meningkatkan kepuasan kerja bawahan, dan membangun identifikasi dengan organisasi. ${ }^{24}$

Dalam rangka peningkatan profesionalisme guru, maka kepala sekolah SMA Negeri 2 Bangkalan, setiap warga sekolah sama-sama memiliki tanggung jawab dalam memajukan sekolah, untuk tanggung jawab bersama itu, kepala sekolah berusaha membagi tugas terhadap para guru khusus guru senior, juga melibatkan guru yunior. Dan ini semua untuk membangun hubungan silaturrahmi dan mitra kerja sesama guru, seperti wakil kepala sekolah diberi kekuasaan dan kebebasan serta diberi kepercayaan terhadap pengambilan keputusan, manakala permasalahan yang akan diputuskan itu sifatnya sangat mendesak.

Adanya pendelegasian terhadap guru itu sudah diatur oleh kepala sekolah. Dengan adanya pendelegasian terhadap guru dan bawahan, berarti guru merasa diberi kesempatan, dan kepercayaan penuh, sehingga dengan sendirinya para guru akan lebih bersemangat lagi untuk meningkatkan kualitas dirinya. Dengan hal itu semua, kepala sekolah berkeyakinan bahwa guru akan terus memacu diri untuk terus berkreatif dan inovatif, yang pada akhirnya akan membawa kemajuan terhadap guru itu sendiri, juga pada lembaga dimana mereka mengabdi.

Kepala sekolah harus memiliki komitmen dan tujuan yang jelas terhadap keberadaan sekolah yang dipimpinnya, mampu mendiskripsikan kepentingan sekolah, membantu para guru dan

${ }^{24}$ Yukl, Gary. Kepemimpinan Dalam Organisasi. Terj. Budi Supriyanto.( Jakarta : Indeks, 2009), 79. 
bawahannya, untuk mengindentifikasi nilai-nilai, tujuan, dan visi misi daripada sekolah, baik intern maupun ekstern, Untuk mewujudkan komitmen tersebut, maka kepala sekolah SMA Negeri 2 Bangkalan, berusaha untuk membangun tim kerja yang solid dan penuh persaudaraan, sehingga kepala sekolah SMA Negeri 2 Bangkalan, mampu dalam usaha meningkatkan kompetensi para guru. Dalam tim tersebut kepala sekolah bersama-sama dengan para guru dan bawahan dengan kompak dalam tugas masing-masing untuk kemajuan bersama, sehingga muaranya akan tercapailah visi, misi, dan tujuan sekolah. Dan kerja keras untuk memajukan sekolah itu tidak lain juga melekat pada para guru yang berkompetens dan berdedikasi tinggi, dan itu disebabkan karena para guru dan bawahan merasa senantiasa diperhatikan dan diperjuangkan, baik peningkatan karir, jenjang kenaikan pangkat.

Oleh karena itu perlu dibina hubungan antar manusia yang sebaik-baiknya sehingga merupakan tim yang dapat bekerja sama dengan penuh kesadaran diantara mereka tanpa ada paksaaan. Dengan demikian, pemimpin harus memberikan perhatian kepada guru dan bawahan di dalam melaksanakan pekerjaan, agar guru dan bawahan merasa diperlukan kehadirannya dan bukan dianggap sebagai alat atau mesin dalam lembaga.

Kepala sekolah selaku pemimpin harus bisa membantu bawahan apabila mengalami kesulitan dalam melaksanakan tugasnya, memberikan rangsangan yang berupa pujian apabila bawahan bekerja dengan berhasil, juga memberikan rangsangan yang berupa insentif bila bawahan memiliki prestasi atau hasil karya yang baik. Hal ini perlu di pupuk dengan baik oleh pemimpin sehingga dengan kerjasama yang baik itu dapat mencapai tujuan yang diharapkan bersama.

Selanjutnya pelaksanaan kerja kepala sekolah dalam meningkatkan profesionalisme guru, Kepala sekolah memberi kepercayaan kepada guru yang dianggap mampu untuk menduduki jabatan strategis, seperti wakil kepala sekolah, kepanitiaan, dan wali kelas maupun dalam melaksanakan pembelajaran di kelas.

Kepala sekolah untuk memimpin mereka adalah dengan memperlakukan bawahan dengan demokratis. Pemimpin yang memiliki sikap demokratis sangat menekankan pengembangan aspek-aspek sosio-emosional, artinya kepala sekolah memberikan kesempatan pada karyawannya untuk ikut mengambil tanggung jawab dalam menegakkan kehidupan kelompok atau lembaga, mengembangkan kesempatan untuk berpartisipasi dalam proses penyusunan rencana kerja dan pengambilan keputusan. 
Pemimpin yang demokratis memiliki ciri-ciri sebagai berikut:

1. Pemimpin selalu mendengar dan memperhatikan aspirasi, kebutuhan, perasaan, interaksi, dan perbedaan-perbedaan individual karyawan; dalam mengerjakan suatu tugas tertentu.

2. Pemimpin lebih menempatkan diri berperan sebagai konusltan, advisor, guru, dan fasilitator, daripada sebagai direktur atau manajer.

3. Pemimpin menempatkan diri sebagai model perilaku yang dapat diteladani pengikutnya.

4. Pemimpin memberikan semangat dan bimbingan kepada pengikutnya untuk mengembangkan ide dan kreativitasnya dalam memecahkan masalah yang dihadapi, dengan mengembangkan tanggung jawab secara mandiri.

5. Dalam melakukan fungsi pengendalian dan evaluasi, pemimpin selalu mengikutsertakan pengikutnya untuk bersama-sama mengambil bagian, termasuk dalam proses pengambilan keputusan. ${ }^{25}$

\section{Evaluasi Kepala Sekolah dalam Meningkatkan Profesionalisme Guru.}

Kepala sekolah dalam prestasi kerja guru dan staf tidak segansegan memberikan apresiasi kepada guru. Berdasarkan temuan peneliti, kepala sekolah memberikan reward dan apresiasi kepada guru yang memliki prestasi dan kinerja memuaskan.

Merujuk pada taksonomi Gary Yukl, dan taksonomi ini memiliki 14 kategori, yang disebut juga oleh Yukl sebagai "praktikpraktik manajerial", salah satu diantara empat belas itu adalah ${ }^{26}$ :

a. Recognizing (Pengakuan).

Memberi pujian dan pengakuan bagi kinerja yang efektif, keberhasilan yang signifikan, kontribusi khusus, mengungkapkan penghargaan terhadap kontribusi dan upayaupaya khusus seseorang.

b. Rewarding (memberi imbalan).

Memberi atau merekomendasikan imbalan yang nyata seperti pertambahan gaji, honorarium atau promosi bagi kinerja yang efektif, keberhasilan yang signifikan, dan kompetensi yang terlihat.

Sesuai dengan taksonomi tersebut, adanya pujian dan pengakuan dari kepala sekolah, maka akan berdampak positip bagi

\footnotetext{
${ }^{25}$ Ibid, 60.

${ }^{26}$ Mulayadi, Kepemimpinan Kepala Sekolah dalam Mengembangkan Budaya Mutu, (Malang: UIN Press, 2010), 48
} 
kinerja guru. Agar guru berkinerja tinggi dan efektif, maka kepala sekolah dalam hal ini ada usaha untuk memberikan penghargaan terhadap kontribusi dan upaya-upaya khusus dari seorang guru maupun bawahannya, kepala sekolah SMA Negeri 2 Bangkalan, memberi pujian, bahkan memberi penghargaan kepada guru yang bersangkutan, pada saat upacara bendera pada hari senin, kepala sekolah mengucapkan terimaksih, kadang juga memberi penghargaan, berupa barang, walaupun barang itu tidak seberapa harganya, akan tetapi nilai pemberian itu jauh lebih penting untuk membangkitkan semangat dalam meningkatkan kompetensi selaku guru, dan bagi guru-guru yang lain hal ini untuk lebih giat lagi dalam menjalankan tugasya, dan memacu semangatnya selaku pengajar dan pembimbing.

Begitu juga dengan adanya insentif. Langkah ini telah dijalankan oleh kepala sekolah SMA Negeri 2 Bangkalan, seperti memberi atau merekomendasikan insentif yang nyata kepada guru dan staf seperti pertambahan gaji, insentif atau honorarium, dalam hal ini kepala sekolah SMA Negeri 2 Bangkalan telah berusaha dalam pemberian insentif pada guru dan bawahannya, dengan tujuannya adalah untuk memberi motivasi kepada guru dan staf dalam melaksanakan tugas. Dalam memberikan insentif, kepala sekolah sesuai dengan usahanya untuk meningkatkan profesionalisme para guru, juga sangat memperhatikan terutama soal keadilan, dan tentunya berimbang dengan usaha kepala sekolah dalam rangka pembinaan, terhadap pemberian insentif pada guru dan semua bawahan, dan semua yang bertugas di SMA Negeri 2 Bangkalan mendapatkan insentif perbulan.

Dalam pemberian insentif terhadap guru dan karyawan yang ada di lingkungan sekolah. disesuaikan dengan keadaan keuangan yang ada, dan juga disesuaikan dengan kapasitas guru dan karyawan setiap bulan semua guru maupun karyawan mendapat insentif, baik itu statusnya sebagai PNS maupun GTT, ataupun tenaga THL dari Pemkab, semuanya mendapat uang insentif, ditambah lagi uang lainlain sesuai dengan tugas dan tanggung jawab masing-masing, semuanya dapat, seperti para guru sesuai dengan banyaknya jam mengajar, jika masih ada tugas lain seperti wali kelas, wakasek, petugas piket kelas semuanya mendapat tambahan insentif, termasuk juga sebagai Pembina ekstra kurikuler semuanya ada anggarannya. Adanya insentif itu adalah salah satu usaha kepala sekolah dalam meningkatkan semangat kerja guru dalam meningkatkan profesionalisme dan kompetensi guru, walaupun sebenarnya hal ini berpulang pada guru masing-masing. 
Kepemimpinan kepala sekolah sangat erat kaitannya dengan kualitas dan kemampuan seorang pemimpin dalam menjalankan fungsi-fungsi kepemimpinan secara efektif dan efisien. Strategi ini dapat dijalankan secara baik apabila diawali dengan sikap dan perilaku pemimpin yang mampu menempatkan dirinya sebagai bagaian dari anggota organisasi.

Strategi akan dapat diwujudkan apabila pemimpin dalam menjalankan interaksi sosial dengan anggota kelompoknya, menunjukkan kemampuannya dalam memahami, memperhatikan dan terlibat dalam masalah-masalah dan kebutuhan organisasi dan anggotanya. Kemampuan itu harus dilakukan dengan memperhatikan batas-batas tertentu agar tidak lebur didalam perasaan, pikiran dan perilaku anggota kelompok, yang dapat berdampak kehilangan peranan atau wibawa sebagai pemimpin.

Strategi kepala sekolah, dalam rangka meningkatkan kompetensi para guru dan bawahannya, kepala sekolah SMA Negeri 2 Bangkalan, adalah sesuai dengan fungsi-fungsi kepemimpinan menggunakan pendekatan partisipatif, istilah lainnya dalam Gary Yukl yang biasa digunakan untuk menyebut aspek kepemimpinan partisipatif mencakup adanya konsultasi, pengambilan keputusan bersama, pembagian kekuasaan (pendelegasian), desentralisasi dan manajemen yang demokratis. ${ }^{27}$ Kepala sekolah SMA Negeri 2 Bangkalan, dalam membuat perencanaan berkonsultasi dan secara fleksibel kepala sekolah melibatkan para guru termasuk dalam hal jika terjadi permasalahan menyangkut tugas guru.

\section{Penutup}

Bertolak dari hasil temuan penelitian tentang implementasi manajemen kepala sekolah SMA Negeri 2 Bangkalan dalam meningkatkan profesionalisme guru, maka peneliti dapat menarik suatu kesimpulan sebagai berikut:

Perencanaan Kepala Sekolah dalam Meningkatkan Profesionalisme Guru adalah pertama, kepala sekolah dalam meningkatkan profesionalisme guru, mengacu kepada visi, misi dan tujuan sekolah, karena visi, misi merupakan rujukan dasar kepala sekolah dalam membawa lembaga pendidikan yang hendak dicapai oleh sekolah. kedua kepala sekolah melakukan pembinaan dan motivasi terhadap para guru dalam meningkatkan profesionalisme guru, dengan melakukan kerjasama dengan MKKS dengan mengadakan pelatihan, workshop, dan kegiatan MGMP.

\footnotetext{
27 Yukl, Gary, Kepemimpinan, 98.
} 
Pelaksanaan Kerja Kepala Sekolah dalam Meningkatkan Profesionalisme Guru adalah; pertama, Kepala sekolah mengadakan supervisi, memberikan bimbingan dan pelatihan terhadap peningkatan profesionalisme para guru, semua itu dilakukan untuk meningkatkan efektivitas dan efesiensi pembelajaran, kedua Kepala sekolah menjadikan guru sebagai mitra kerja, dalam membuat kebijakan dan keputusan bersama, bahwa program sekolah berjalan dengan baik ketika ada sinergi antara sekolah dengan para guru.

Evaluasi Kepala Sekolah dalam Meningkatkan Profesionalisme Guru adalah; pertama, Kepala sekolah memberikan reward terhadap guru yang berprestasi dan melakukan shering bersama. kedua, Kepala sekolah memberi kepercayaan kepada guru yang dianggap mampu untuk menduduki jabatan strategis, seperti wakil kepala sekolah, kepanitiaan, dan wali kelas.

\section{Daftar Pustaka}

Aila, Hendrati. Seratus Lima Puluh Prinsip Sukses Kepemimpinan Terdahsyat, Yogyakarta: Sepanjang Sejarah, Pinang Merah, 2011)

Ali Nur, Murni Wahid. Penelitian Tindakan kelas, Pendidikan Agama dan Umum, (disertai Contoh Hasil Penelitian, UIN Malang, 2008)

Brodjonegoro, Kualitas SDM Indonesia, (Pikiran Rakyat, 2005)

Depdiknas, Rencana Strategis Depdiknas, (Jakarta: Depdiknas, 2005) Gary, Yukl. Kepemimpinan Dalam Organisasi. Terj. Budi Supriyanto,

(Jakarta: Indeks, 2009)

Hadi, Sutrisno, Metodologi Research II, (Andi Offset, 1994)

Hasan H. Guru Yang Profesional, (Bandung: UPI, 2003)

Iskandar, Mukhtar, Orientasi Baru supervisi Pendidikan, (Jakarta: Gaung Persada, 2009)

Kartono Kartini, Pengantar Metodologi Riset Sosial. (Bandung: Mandar Maju, 1996)

Marno, Supriyatno Triyo, Manajemen dan Kepemimpinan Pendidikan Islam, (Bandung: PT Refika Aditama, 2008)

Muhaimin, Nuansa Baru Pendidikan Islam, Mengurai Benang Kusut Dunia Pendidikan, (Jakarta: PT Radja Grafindo Persada, 2006) Mulyadi, Kepemimpinan Kepala Sekolah dalam mengembangkan Budaya Mutu, (Malang: UIN Press, 2010)

Nasir Moh. Metode penelitian, (Jakarta: Ghlmia Indonesia, 2003) 
Nawawi Hadari, Martini Mimi, Penelitian Terapan, (Yogyakarta: Gajah Mada University Press, 1994)

Nurhayati, HadisAbdul, 2010, Manajemen Mutu Pendidikan, Bandung: Alfabeta, 2010)

Sa'ud Saefudin Udin, Inovasi Pendidikan, (Bandung: Alfabeta, 2008)

Saroni Muhamad, Manajemen Sekolah, (Yogyakarta: Ar-Ruzz Media, 2006)

Soetopo Hendiyat, Manajemen Berbasis Sekolah dan Kurikulum

Berbasis Kompetensi, Bunga Rampai Pokok Pikiran

Pembahasan Pendidikan Indonesia, (Malang: Universitas

Negeri Malang Program Pascasarjana, 2007)

Sofyan Effendi Masri Singarimbun, (Ed.) Metode Penelitian Survey,

(Jakarta: LP3ES, 1994)

Sofyan Effendi Masri Singarimbun, (Ed.). Metode Penelitian Survey,

(Jakarta: LP3ES, 1994)

Suaidan, Al Thariq Muhammad, Shina'atu Al-Qoid, Trj. Najib Junadi, (Surabaya: Pustaka Yasir, 2005)

Suhardana Dadang, Supervisi Profesional Layanan dalam Meningkatkan Mutu Pembelajaran di Era Otonomi Daerah, Bandung: Alfabeta, 2010)

Suharsimi, Arikunto. Prosedur Penelitian; Suatu Pendekatan Praktek, Jakarta: Rineka Cipta, 1993)

Sulistyorini. Manajemen pendidikan Islam, (Surabaya: el.KAF, 2006) Thoha Miftah, Perilaku Organisasi Konsep Dasar dan Aplikasinya, PT (Jakarta: RajaGafindo Persada, 2010)

Tilaar H.A.R. Manajemen Pendidikan Nasional, (Bandung: Remaja Rosdakarya, 2001)

Wahjosumidjo, Kepemimpinan Kepala Sekolah, (Jakarta: RajaGrafindo Persada, 1994) , (tinjauan teoritik dan permasalahan) Kepemimpinan

Kepala sekolah. Jakarta Raja Grafindo Persada, 1999)

Wijaya Cece, dkk. Kemampuan dasar dalam Proses Belajar Mengajar, (Bandung: PT. Remaja Rosdakarya, 1999)

Wuradji., The Educational Leadership, Kepemimpinan Transformasional. (Yogyakarta: Gama Media, 2008) 